\section{The Prevalence and Risk Factors of Allergic Diseases in School-Age Athletes in Southwest of Turkey: A Cross-Sectional Questionnaire Study}

\author{
Türkiye'nin Güney Batısında Okul Çağındaki \\ Atletlerde Alerjik Hastalık Prevalansı ve Risk \\ Faktörleri: Kesitsel Anket Çalışması
}

\section{Şennur Keleş $\odot$
Serkan Filiz $\odot$
Ali Eraslan $\odot$
Gufat Arslan $\odot$
Furkan Bakkal $\odot$ \\ Muhammed Furkan Bakkal ๑}

(1)

\section{ABSTRACT}

Objective: The prevalence and the risk factors influencing allergic disorders in amateur athletes are still poorly defined. The aim of this study was to evaluate the prevalence and risk factors of the common allergic disorders in school aged athletes compared with the general population in southwest of Turkey. Methods: Using the "International Study of Asthma and Allergy in Childhood (ISAAC) Phase I" questionnaire, 714 athletes aged $7-18$ and 325 age-matched healthy controls were examined. Risk factors that would affect the prevalence were evaluated with the questions given in addition to this questionnaire.

Results: In the athlete group, the prevalence of existing asthma, allergic rhinitis, and eczema was lower than controls [(3.8\%) and (16.3\%), respectively, $p<0.001]$, [(18.7\%) and $(42.1 \%)]$, respectively, $p<0.001]$ and $[(5.5 \%)$ and $(10.5 \%)$, respectively, $p<0.001]$. Multivariate logistic regression analysis revealed that in the athlete population, a previously known allergy increased risk of curent wheezing (odds ratio [OR] =5.3; confidence interval, $[\mathrm{Cl}]=1.8-15.4)$, current allergic rhinitis $([\mathrm{OR}]=2.8 ;[\mathrm{Cl}]=1.3-6.2)$, and current eczema $[O R]=4.5 ;[C l]=1.1-17.1)$. Familial atopy increased risk of current allergic rhinitis $(O R=2.2 ; C l=0.9-4.9)$, and current eczema $([O R]=6.6 ;[\mathrm{Cl}]=1.7-25.7)$.

Conclusion: This study is the first prevalence study using the ISAAC method in school-age sports children in southwestern Turkey. Unlike adults, the prevalence of asthma, allergic rhinitis and eczema was found to be lower than controls of the same age. It is thought that sports and spending more time outdoors in children reduce allergic inflammation.

Keywords: School age, children, allergic disease, sports, prevalence, athlete

öz

Amaç: Spor yapan çocuklarda alerjik hastalıkların sıklığı ve bu hastalıklara yol açan risk faktörleri tam olarak tanımlanmamıştır. Bu çalışma,Türkiye'nin güneybatısında okul çağındaki sporcularda alerjik hastalıkların sıklığını ve risk faktörlerini araştırmayı amaçlamaktadır.

Yöntem: Kesitsel, prospektif bu çalışmaya 7-18 yaş arası 714 sporcu ve yaş uyumlu 325 sağlıklı kontrol grubu alınmıştır. Alerjik hastalıkların prevalansı için "International Study of Asthma and Allergy in Childhood (ISAAC) Phase I"anketi kullanılmış, prevalansı etkileyecek risk faktörleri ise bu ankete ek olarak verilen sorular ile değerlendirilmiştir.

Bulgular: Okul çağındaki sporcu çocuklarda; astım $(\% 3,8)$, alerjik rinit $(\% 18,7)$ ve egzama $(\% 5,5)$ sıklı̆̆ kontrol grubundaki astım $(\% 16,3)$, alerjik rinit $(\% 42,1)$ ve egzama (\%10.5) sıklığına göre daha düşük idi (sırasıyla $p<0,001, p<0,001, p<0.001$ ). Çok değişkenli lojistik regresyon analizinde okul çağındaki sporcu çocuklarda daha önce bilinen bir alerjik hastalık olmasının, mevcut hışıltı(odds oranı [OR]=5.3; güven aralığı, $[\mathrm{Cl}]=1.8-15.4)$, alerjik rinit $([O R]=2.8 ;[\mathrm{CI}]=1.3-6.2)$ ve egzama $([O R]=4.5 ;[\mathrm{CI}]=1.1-17.1)$ için önemli bir risk faktörü olduğunu gösterdi. Ailede atopi varlığının alerjik rinit ([OR]=2.2; [Cl]=0.9-4.9) ve egzama ([OR] $=6.6 ;[C I]=1.7-25.7)$ ile istatistiksel olarak anlamlı ilişkisi olduğu saptandı.

Sonuç: Bu çalışma Türkiye'nin güneybatısında okul çağındaki sporcu çocuklarda ISAAC yöntemi kullanılarak yapılan ilk prevalans çalışmasıdır. Çalışmada erişkinlerden farklı olarak astım, alerjik rinit ve egzama prevalansı aynı yaştaki kontrollere göre daha düşük bulunmuştur. Çocuklarda sporun ve dış ortamda daha fazla zaman geçirmenin alerjik inflamasyonu azalttığı düşünülmüş̧ür.

Anahtar kelimeler: Okul çağı, çocuklar, alerjik hastalıklar, spor, prevalans, atlet 


\section{INTRODUCTION}

Estimating the incidence and prevalence of allergic disorders such as asthma, allergic rhinitis and eczema, is challenging worldwide. Allergies are affected by environmental factors, including diet, infections, exposure to air pollutants and occupational exposure (1). A large proportion of the young population undertake exercise and amateur sports in various disciplines ${ }^{(2)}$.

Recent epidemiological studies have reported that the prevalence of asthma and rhinitis in athletes is higher than in the normal population ${ }^{(3,4)}$. In contrast, some studies have found that doing sport does not affect allergic symptoms, including asthma and rhinitis ${ }^{(5,6)}$. The relationship between sports activities and allergies in school children is not yet fully understood. It is seen that the problems regarding the management and prevention of allergic symptoms in this age group continue ${ }^{(7)}$.

Allergic diseases can decrease sports performance through deteriorations in quality of life, sleep disturbances and inadequate training ${ }^{(8-10)}$. Exerciseinduced (EI) allergic disorders are complex, frustrating and distressing for both patients and physicians. The respiratory (asthma, bronchospasm and rhinitis), cutaneous (urticaria and angio-oedema) or cardiovascular (anaphylaxis) systems are usually targeted ${ }^{(11)}$.

Asthma and rhinitis are more common in competitive athletes because of airway dehydration from hyperpnea, increased exposure to aeroallergens and airway injury caused by irritant chemicals and the environment ${ }^{(3,4,11)}$.

The prevalence of allergic diseases shows a great variability and differs not only between countries but also among various regions of the same country (12) (The International Study of Asthma and Allergies in Childhood (ISAAC) Steering Committee). Worldwide variations have been reported in the prevalence of symptoms of asthma, allergic rhinoconjunctivitis and atopic eczema ${ }^{(13)}$. The inconsistencies in rates can also be attributed to methodological differences between studies, such as variations in the age range of study participants
(12). In recent years, there are many studies on the prevalence of asthma and allergic diseases in our country. Prevalence studies have reported a frequency of $2.8 \%$ to $13.4 \%$ for asthma, $3.4 \%$ to $13.3 \%$ for wheezing, $4.5 \%$ to $17.3 \%$ for allergic rhinitis, and $0.9 \%$ to $4.6 \%$ for atopic dermatitis ${ }^{(12,14-20)}$.

To the best of our knowledge, there is no epidemiological study about allergic diseases in young athletes in the southwest of Turkey. Therefore, the aim of this survey-based study was to investigate the prevalence and risk factors of asthma, allergic rhinitis and eczema in young Turkish athletes, and to compare the results with an age-matched control group.

\section{MATERIAL and METHODS}

\section{Study Population and Design}

This cross-sectional study was conducted between June 2019 and January 2020, using the ISAAC Phase I method on a group of children aged 7-18 years (n:714), who presented at the Sports Medicine Department of our hospital requesting a medical certificate testifying to their suitability to practise a sport (mandatory by Turkish law for participation in sports). The control group was formed of sexmatched volunteer children aged 7-18 years, randomly selected from the general population ( $n: 325)$. Parents were asked to complete the International Study of Asthma and Allergies in Childhood (ISAAC) phase I questionnaire, which has been previously validated for the Turkish population ${ }^{(13,21)}$. An additional questionnaire was prepared and used to identify related risk factors for allergy. The research was reviewed and approved by the Institutional Review Board, (2019-222, 16/11) and informed consent was provided by a parent of each subject.

\section{Questionnaires}

Parents were questioned about allergic diseases of their child such as asthma, allergic rhinitis and atopic dermatitis, using the International Study of Asthma and Allergies in Childhood (ISAAC) phase I questionnaire. Risk factors that would affect the 
prevalence were evaluated with the questions given in addition to this questionnaire. The additional questionnaire included items about the income level of the family, number of persons in the household, the presence of a separate bedroom for the child, home heating system, educational levels of the parents, employment status of the parents, prematurity, duration of breastfeeding, the time of starting supplementary foods, pet ownership, and tobacco smoke exposure at home and during pregnancy. Income was classified in three levels as 'lower than 300 USD, between 300-750 USD and higher than 750 USD. Famial atopy was defined as a positive history or diagnosis of asthma, rhinitis, and/ or eczema in one or both of the parents.

\section{Definitions and terms}

Individuals were requested to reply to questionnaire which contained questions regarding the terms below ${ }^{(22)}$.

- Wheeze ever: Have you ever had wheezing or whistling in the chest at any time in the past?

- Current wheezing: In the past 12 months, have you had wheezing or whistling in the chest?

- Severe wheeze in the past year: In the past 12 months, has wheezing ever been severe enough to limit your speech to only 1 or 2 words at a time between breaths?

- Asthma ever: Have you ever had asthma?

- Exercise-induced wheeze in the past year: In the past 12 months, has your chest sounded wheezy during or after exercise?

- Nocturnal cough in the past year: In the past 12 months, have you had a dry cough at night, apart from a cough associated with a cold or a chest infection?

- Allergic rhinitis ever: Have you ever had a problem with sneezing, or a runny, or a blocked nose when you did not have a cold or the flu?

- Current allergic rhinitis: In the past 12 months, have you had a problem with sneezing, or a runny, or a blocked nose when you did not have a cold or the flu?
- Current rhinoconjunctivitis: In the past 12 months, has this nose problem been accompanied by itchy/watery eyes?

- Hay fever ever: Have you ever had hay fever?

- Itchy rash ever: Have you ever had an itchy rash which came and went for at least 6 months?

- Current itchy rash: Have you had this itchy rash at any time in the past 12 months?

- Itchy flexural rash in the last year: Has this itchy rash at any time affected any of the following places: the folds of the elbows, behind the knees, in front of the ankles, under the buttocks, or around the neck, ears or eyes?

- Eczema ever (skin allergy ever): Have you ever had eczema (skin allergy)?

\section{Statistical Methods}

Data obtained in the study were analysed statistically using SPSS vn. 23.0 software. Descriptive statistics were presented as mean, standard deviation, median, IQR, minimum and maximum values, or number $(\mathrm{n})$ and percentage (\%). Conformity of the data to normal distribution was assessed using the Kolmogrov- Smirnov test. The Chi- square test, Fisher Exact Test and Mann Whitney U-test were used to compare groups. For the multivariate analysis, the possible factors identifed with univariate analyses were then entered into the logistic regression analysis to determine independent predictors of asthma, allergic rhinitis and eczema outcome. Hosmer-Lemeshow goodness of fit statistics were used to assess model fit. $A$ value of $p$ $<0.05$ was considered statistically significant.

\section{RESULTS}

The athletes group comprised $67.9 \%$ males with mean height of $155 \pm 17 \mathrm{~cm}$ (range, $110-197 \mathrm{~cm}$ ) and the control group comprised $54.8 \%$ males with mean height of $152 \pm 18 \mathrm{~cm}$ (range, $110-187 \mathrm{~cm})(p<0.0001$, $p=0.019)$. The demographic characteristics of the study participants are summarized in Table 1.

The sports practised most frequently in the 
Table 1. The demographic characteristics of the groups.

\begin{tabular}{|c|c|c|c|}
\hline & AG & CG & $p$ value \\
\hline No of subjects (\%) & $714(68.7 \%)$ & $325(31.3 \%)$ & 0.801 \\
\hline Age (years) (mean $\pm S D)$ & $12.65 \pm 2.88$ & $12.72 \pm 3.34$ & $<0.0001^{*}$ \\
\hline Male/Female & $485 / 229$ & $178 / 147$ & 0.019 \\
\hline Height $(\mathrm{cm})($ mean $\pm S D)$ & $155 \pm 17$ & $152 \pm 18$ & 0.198 \\
\hline BMI (mean $\pm S D)$ & $19.29 \pm 3,53$ & $19.69 \pm 3,83$ & 0.484 \\
\hline Previously known allergy n (\%) & $69(9.7)$ & 36 (11.1\%) & $<0.0001$ \\
\hline Familial atopy $\mathrm{n}(\%)$ & $65(9.1)$ & $80(24.6)$ & \\
\hline \multicolumn{4}{|l|}{ Income level n (\%) } \\
\hline$<300$ USD & $139(20.1)$ & $42(13.3)$ & $0.004 *$ \\
\hline 300-750 USD & $446(64.5)$ & $204(64.6)$ & \\
\hline >750 USD & $107(15.5)$ & $70(22.2)$ & \\
\hline Total & $692(100)$ & $316(100)$ & \\
\hline \multicolumn{4}{|l|}{ Maternal education $\mathrm{n}(\%)$} \\
\hline Primary school & $171(24.1)$ & $75(23.3)$ & 0.68 \\
\hline Secondary school & $107(15.1)$ & $52(16.1)$ & \\
\hline High school & $220(31)$ & $90(28)$ & \\
\hline University & $211(29.8)$ & $105(32.6)$ & \\
\hline Total & $709(100)$ & $322(100)$ & \\
\hline \multicolumn{4}{|l|}{ Paternal education $\mathrm{n}(\%)$} \\
\hline Primary school & $145(20.4)$ & $53(16.6)$ & $0.002 *$ \\
\hline Secondary school & 99 (13.9) & 40 (12.5) & \\
\hline High school & $241(33.8)$ & $85(26.6)$ & \\
\hline University & 227 (31.9) & $142(44.4)$ & \\
\hline Total & $712(100)$ & $320(100)$ & \\
\hline Gestational age ( $\leq 37$ weeks) & $34(4.9 \%)$ & $18(5.9 \%)$ & 0.52 \\
\hline Breast feeding (mean $\pm S D$ ) & $16.49 \pm 9.25$ & $15.31 \pm 8.43$ & 0.17 \\
\hline $\begin{array}{l}\text { Starting supplementary } \\
\text { food (mean } \pm S D)\end{array}$ & $6.17 \pm 1.6$ & $6.12 \pm 1.6$ & 0.84 \\
\hline Smoking at home $\mathrm{n}(\%)$ & $177(25.5)$ & $105(33.5)$ & $0.008 *$ \\
\hline $\begin{array}{l}\text { Smoking during pregnancy } \\
\text { Home type } n(\%)\end{array}$ & $42(6.1)$ & 41 (12.9) & $<0.0001^{*}$ \\
\hline Apartment & $624(87.8)$ & $248(76.5)$ & $<0.0001^{*}$ \\
\hline Detached house & $60(8.4)$ & $58(17.9)$ & \\
\hline Slum area dwelling & $27(3.8)$ & $18(5.6)$ & \\
\hline Total & $711(100)$ & $324(100)$ & \\
\hline $\begin{array}{l}\text { Duration of doing sports } \\
\text { (years) mean } \pm S D\end{array}$ & $2.68 \pm 2.29$ & & \\
\hline
\end{tabular}

Values in parentheses are percentages; ${ }^{*} p<0.05$ is statistically significant, AG: Athletes Group, CG: Control Group, SD: Standard Deviation.

athletes group were football (25.2\%) and basketball (24.4\%). The athletes had been playing sports for an average of $2.68 \pm 2.29$ years. The sport disciplines and categories are summarized in Figure 1 . There was a positive association between doing sports and income level below 300 USD per month and above 750 USD per month $(p=0.004)$. In the athlete group, there was a higher rate of fathers with college level education $(p=0.002)$.

Maternal education status, prematurity, a separate bedroom, number of people living in the home, home heating system, and pet ownership

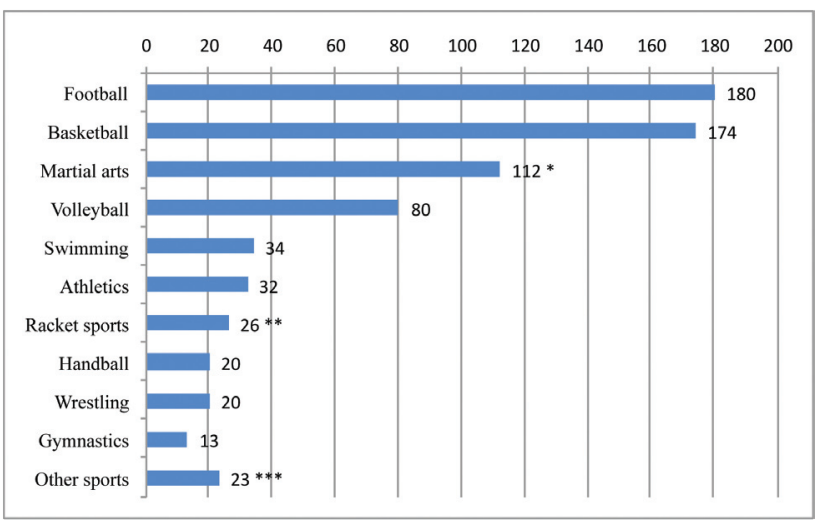

*Taekwondo, Kick-boxing, Muay-thai, Karate, Judo

**Tennis, Table tennis, Squash, Badminton

***Archery, Cycling, Orienteering, Weightlifting, Hockey, Skating

Figure 1. Distribution of the athletes according to sport disciplines.

Table 2. Responses to the key questions of the questionnaire.

\begin{tabular}{lccc}
\hline Question & AG & CG & p \\
\hline Wheeze ever & $45(6.3)$ & $86(26.5)$ & $<0.0001^{*}$ \\
Current wheeze & $27(3.8)$ & $53(16.3)$ & $<0.0001^{*}$ \\
Attacks of wheezing in last year & & & \\
- 1-3 & $21(2.9)$ & $41(12.6)$ & $<0.0001^{*}$ \\
- 4-12 & $6(0.8)$ & $10(3)$ & \\
- $<12$ & $0(0)$ & $1(0.3)$ & \\
Sleep disturbed by wheeze in & & & \\
last year & & & \\
- Never woken with wheezing & $15(2.1)$ & $24(7.3)$ & $<0.0001^{*}$ \\
- Less than one night per week & $11(1.5)$ & $24(7.3)$ & \\
- One or more nights per week & $2(0.3)$ & $5(1.5)$ & \\
Severe attacks of wheeze limi- & $3(0.4)$ & $21(6.7)$ & \\
ting speech in last year & & & \\
Doctor-diagnosed asthma & $32(4.5)$ & $35(10.8)$ & $<0.0001^{*}$ \\
Wheeze after exercise in last year & $13(1.8)$ & $27(8.3)$ & $<0.0001^{*}$ \\
Waking with cough in last year & $37(5.2)$ & $78(24)$ & $<0.0001^{*}$ \\
Allergic rhinitis ever & $167(23.4)$ & $158(48.6)$ & $<0.0001^{*}$ \\
Current rhinitis & $134(18.8)$ & $137(42.2)$ & $<0.0001^{*}$ \\
Current rhinoconjunctivitis & $46(6.4)$ & $65(20)$ & $<0.0001^{*}$ \\
Doctor-diagnosed allergic rhi- & $36(5)$ & $44(13.5)$ & $<0.0001^{*}$ \\
nitis & & & \\
Itchy rash ever & $29(4.1)$ & $42(12.9)$ & $<0.0001$ \\
Current itchy rash & $18(5.5)$ & $34(10.5)$ & $<0.0001^{*}$ \\
Itchy flexural rash in the last year & $13(1.8)$ & $24(7.4)$ & $<0.0001^{*}$ \\
Doctor-diagnosed eczema & $17(2.4)$ & $12(3.7)$ & 0.23 \\
& & & \\
& & &
\end{tabular}

Values in parentheses are percentages; ${ }^{*} p<0.05$ is statistically significant, AG: Athletes Group, CG: Control Group.

were not correlated with doing sports. The prevalence of ever wheeze, current wheeze, doctor diagnosed asthma, ever rhinitis, current rhinitis, current rhinoconjunctivitis, doctor diagnosed conjunctivitis, itchy rash ever, current itchy rash and doctor 
diagnosed eczema was lower in the athlete group (6.3\%, 3.8\%, 4.5\%, 23.4\%, 18.8\%, 6.4\%, 5.0\%, 4.1\%, $5.5 \%, 2.4 \%$ ) compared to the control group (26.5\%, $16.3 \%, 10.8 \%, 48.6 \%, 42.2 \%, 20.0 \%, 13.5 \%, 12.9 \%$, $10.5 \%, 3.7 \%, p<0.001$, respectively). The prevalence rates of atopic eczema, allergic rhinitis and asthma are shown in Table 2. Differences were determined in sex, height, family income level, and paternal education level. After adjustment for potential confounders, the athletes showed no statistically significant increased risk for asthma, allergic rhinitis or eczema. When the influences were evaluated with multivariate logistic regression analysis, in the athlete population, a previously known allergy was associated with a statistically significant increased risk of curent wheezing $(\mathrm{OR}=5.3 ; \mathrm{Cl}=1.8-15.4)$, current allergic rhinitis (OR=2.8; $\mathrm{Cl}=1.3-6.2)$, and current eczema (OR 4.5; 95\% Cl 1.1-17.1). Familial atopy was associated with a statistically significant increased risk of current allergic rhinitis $(\mathrm{OR}=2.2 ; \mathrm{Cl}=0.9-4.9)$, and current eczema ( $\mathrm{OR}=6.6 ; \mathrm{Cl}=1.7-25.7)$. A seasonal difference in complaints was associated with a statistically significant increased risk of current allergic rhinitis (OR=7.7; $\mathrm{Cl}=2.9-20.5$ ) in comparsion with the control group.

\section{DISCUSSION}

Epidemiologic studies have demonstrated that the prevalence of allergic diseases have increased progressively over the last few decades in worldwide. Likewise, a rising trend of asthma and allergy have also been observed among competitive athletes ${ }^{(4,23,24)}$. The studies demonstrated that the prevalence of rhinitis in elite athletes was highly variable, ranging from $16.8 \%$ to $56.0 \%$ and the and the prevalence of asthma between $3.7 \%$ and $22.8 \%$, depending on the study population and methods used for diagnosis (25-29). Therefore, asthma and asthma-like symptoms occur very frequently in elite athletes compared with age-matched control subjects. It has been shown in ongoing studies that the frequency of the disease continues in comparable population samples (24,29-31). Most of the studies examining the relationship between allergy and sports have been conducted on elite or Olympic athletes who are quite heterogeneous in terms of age, gender, geographical origin and type of sport. The training programs of these athletes differ considerably from those of non-professional young amateur athletes ${ }^{(32)}$.

Unlike previous elite athlete studies, we showed that there is no increased risk of allergic diseases in school-age athlete children in our study. In Turkey, school-age children in must obtain a physical fitness certificate from the Sports Medicine Center in order to participate in any sports activity. Since almost all the residents of Antalya who are involved in sports are examined at the Sports Medicine Center, it can be considered that the study sample is probably quite representative of the entire athlete population in the region. Macucci et al. ${ }^{(33)}$ assessed the prevalence of asthma and related respiratory symptoms in a sample of the Siena pediatric population engaged in sport. The subjects were 460 young athletes, aged 7-14 years, and the lifetime prevalences of asthma, allergic rhinitis and atopic dermatitis were found to be $17.33 \%, 22.16 \%$ and $11.08 \%$, respectively. Kurowski et al. ${ }^{(24)}$ found the prevalence of diagnosed asthma to be $5.9 \%$ and allergic rhinitis $21.0 \%$ among Olympic athletes, which was similar to the prevalence in the current study .

The prevalence of self reported asthma in the athletes of the present study was roughly similar to the findings of previous studies of amateur endurance-trained athletes ${ }^{(5,6,34)}$. Tardivo et al. (5) reported the prevalence of ever asthma and current asthma to be lower in athletes $(4.0 \%, 3.0 \%)$ than in the general population $(11.0 \%, 4.8 \%)$, asthma was found to be less common in amateur athletes than in the general population and the risk of asthma and respiratory symptoms was associated more with outdoor sports than indoor, but not with any particular type of exercise. Ventura et al. ${ }^{(32)}$ studied 194 soccer players in age groups of beginners (8-11 years), juniors (12-16 years) and under 21 (17-20 years). The prevalence of allergic diseases was $34.5 \%$ in the soccer players and $31.6 \%$ in the control subjects, skin sensitization to inhalant allergens was detected in $14.4 \%$ of symptomatic soccer players and in $19.2 \%$ of the control subjects, and patch tests were positive in $35.7 \%$ of the soccer players and 
$23.0 \%$ of the control subjects with allergic dermatitis $(p>0.05)$. The prevalence of allergic diseases did not significantly change in relation to the intensity of training. Although the relative prevalence of sensitization to perennial allergens and asthma was less frequent in the soccer players than in the control group, sensitization to pollens was relatively $(p<0.05)$ more frequent in the soccer players than in the control group ( $64.3 \%$ vs $20.0 \%$ ) while sensitization to dust mites occurred relatively more often in the control group (50.0\% vs $14.3 \%)$. In the current study, when the groups were separated into age groups of 7-12 years and 13-18 years to exclude the age effect, no significant change was determined in the prevalence of allergic disease.

In another study in Trabzon, northern Turkey, which investigated the prevalence of exercise-induced bronchospasm (EIB) in football players aged 8-18 years, the prevalence of a history of doctor-diagnosed asthma or allergic rhinitis was $0.9 \%$ and $2.1 \%$ respectively and a reduction in FEV 1 of $\geq 10 \%$ was observed after exercise in $22(9.6 \%)$ children ${ }^{(35)}$. In the current study, EIB was not diagnosed in any of the children with doctor-diagnosed asthma or allergic rhinitis. No difference was determined in the prevalence of EIB between children who reported or did not report ever wheezing, current wheezing, a whistle in the chest after running and playing in the last 12 months, and symptoms of allergic rhinitis. None of the children reported symptoms of atopic dermatitis or had doctor-diagnosed atopic dermatitis. Exercise testing was not performed in this study, but the prevalence of wheeze after exercise was reported to be $1.8 \%$. This may be due to a belief that a child with a chronic respiratory disease such as asthma should avoid any activities including strenuous exercise.

The current study results showed that seasonal complaints were a risk factor for allergic rhinitis. It can be speculated that outdoor activities might increase the airway exposure to environmental factors, such as air pollutants or pollen allergens (36,37). Asthma and allergy are caused by complex mechanisms and their interaction. Personal factors (familial atopy) and environmental factors play an important role on an individual basis ${ }^{(18,38)}$.
The main result of this study was that the prevalence of self-reported asthma and allergic diseases was lower in athletes than in the control group. It should be taken into account that many differences such as genetic variability, geographical conditions, differences in exercise intensity and duration, and other lifestyles factors may have an effect on this ${ }^{(39)}$. Although intense regular training over long periods of time may contribute to the development of asthma and other respiratory allergies, regular aerobic training promotes health and may prevents allergic disease by decreasing the systemic inflammation. Physical exercise has been shown to regulate chronic allergic inflammation by modulating cytokines ${ }^{(40,41)}$.

Limitations of this study were primarily the low number of control group children from the general population, the questionnaire-based design and the fact that information bias could not be completely ruled out as there were no face-to-face interviews.

In conclusion, based on the results of this study, the prevalence of self-reported asthma, allergic rhinitis and eczema were seen to be lower in Turkish school-age athletes than in age-matched control subects. Unlike professional athletes, the frequency of allergic diseases is less common among amateur athletes. Previously known allergy and family atopy can be considered to increase the risk of allergic diseases. This study can provide a basis for studies that will have broader involvement, as there is a need for further more extensive studies on this subject using standard survey forms.

Acknowledgements: The authors thank all the subjects who participated in this study and their parents.

Ethics Committee Approval: S.B.U. Antalya Training and Research Hospital Clinical Research Ethics Committee approval was obtained (2019/222).

Conflict of Interest: The authors have no conflict of interests to declare.

Funding: The authors declare that this study received no financial support.

Informed Consent: Yes. 


\section{REFERENCES}

1. Devereux G MEC, Burney PGJ. Epidemiology of Asthma and Allergic Diseases. Middleton's Allergy Principles and Practice 8ed2013. p. 755-83.

2. Del Giacco S, Manconi P, Del Giacco G. Allergy and sports. Allergy. 2001;56(3):215.

https://doi.org/10.1034/j.1398-9995.2001.056003215.x

3. Helenius I, Haahtela T. Allergy and asthma in elite summer sport athletes. Journal of Allergy and Clinical Immunology. 2000;106(3):444-52.

https://doi.org/10.1067/mai.2000.107749

4. Carlsen K, Anderson S, Bjermer L, Bonini S, Brusasco V, Canonica W, et al. Exercise-induced asthma, respiratory and allergic disorders in elite athletes: epidemiology, mechanisms and diagnosis: Part I of the report from the Joint Task Force of the European Respiratory Society (ERS) and the European Academy of Allergy and Clinical Immunology (EAACI) in cooperation with GA2LEN. Allergy. 2008;63(4):387-403. https://doi.org/10.1111/j.1398-9995.2008.01662.x

5. Tardivo S, Zerman T, Frizzera S, Locatelli F, Ferrari P, Schenk K, et al. Self-reported asthma and respiratory symptoms among Italian amateur athletes. European Journal of Sport Science. 2012;12(1):96-102.

https://doi.org/10.1080/17461391.2010.545437

6. Kippelen P, Caillaud C, Coste O, Godard P, Prefaut C. Asthma and exercise-induced bronchoconstriction in amateur endurance-trained athletes. International journal of sports medicine. 2004;25(02):130-2.

https://doi.org/10.1055/s-2004-819944

7. Kusunoki T, Takeuchi J, Morimoto T, Sakuma M, Mukaida K, Yasumi T, et al. Sports activities enhance the prevalence of rhinitis symptoms in schoolchildren. Pediatric Allergy and Immunology. 2016;27(2):209-13.

https://doi.org/10.1111/pai.12516

8. Katelaris $\mathrm{CH}$, Carrozzi FM, Burke TV, Byth K. Patterns of allergic reactivity and disease in Olympic athletes. Clinical Journal of Sport Medicine. 2006;16(5):401-5.

https://doi.org/10.1097/01.jsm.0000244606.56935.59

9. Graham DM, Blais MS. Quality-of-life outcomes measures of asthma and allergic rhinitis. Pediatric annals. 2000;29(7):43843. https://doi.org/10.3928/0090-4481-20000701-12

10. Walker S, Khan-Wasti S, Fletcher M, Cullinan P, Harris J, Sheikh A. Seasonal allergic rhinitis is associated with a detrimental effect on examination performance in United Kingdom teenagers: case-control study. Journal of Allergy and Clinical Immunology. 2007;120(2):381-7. https://doi.org/10.1016/j.jaci.2007.03.034

11. Schwartz L, Delgado L, Craig T, Bonini S, Carlsen K, Casale T, et al. Exercise-induced hypersensitivity syndromes in recreational and competitive athletes: a PRACTALL consensus report (what the general practitioner should know about sports and allergy). Allergy. 2008;63(8):953-61.

https://doi.org/10.1111/j.1398-9995.2008.01802.x

12. Civelek E, Yavuz ST, Boz AB, Orhan F, Yuksel H, Uner A, et al. Epidemiology and burden of rhinitis and rhinoconjunctivitis in 9-to 11-year-old children. American journal of rhinology \& allergy. 2010;24(5):364-70. https://doi.org/10.2500/ajra.2010.24.3484

13. Worldwide variation in prevalence of symptoms of asthma, allergic rhinoconjunctivitis, and atopic eczema: ISAAC. The International Study of Asthma and Allergies in Childhood
(ISAAC) Steering Committee. Lancet. 1998;351(9111):122532.

https://doi.org/10.1016/S0140-6736(97)07302-9

14. Türktaş I, Selçuk ZT, Kalyoncu AF. Prevalence of asthmaassociated symptoms in Turkish children. The Turkish journal of pediatrics. 2001;43(1):1-11.

15. Kalyoncu A, Selcuk Z, Karakoca Y, Emri A, Cöplü L, Şahin A, et al. Prevalence of childhood asthma and allergic diseases in Ankara, Turkey. Allergy. 1994;49(6):485-8. https://doi.org/10.1111/j.1398-9995.1994.tb00846.x

16. SELÇUK ZT, Caglar T, Enünlü T, Topal T. The prevalence of allergic diseases in primary school children in Edirne, Turkey. Clinical \& Experimental Allergy. 1997;27(3):262-9. https://doi.org/10.1111/j.1365-2222.1997.tb00704.x

17. Demir AU, Karakaya G, Bozkurt B, Şekerel BE, Kalyoncu AF. Asthma and allergic diseases in schoolchildren: third cross-sectional survey in the same primary school in Ankara, Turkey. Pediatric allergy and immunology. 2004;15(6):531-8. https://doi.org/10.1111/j.1399-3038.2004.00202.x

18. Kurt E, Metintas S, Basyigit I, Bulut I, Coskun E, Dabak S, et al. Prevalence and risk factors of allergies in Turkey: results of a multicentric cross-sectional study in children. Pediatric Allergy and Immunology. 2007;18(7):566-74. https://doi.org/10.1111/j.1399-3038.2007.00551.x

19. Akçay A, Duksal F, Becerir T, Ergin A, Güler N. The prevalence of atopic dermatitis in adolescents living in Denizli, Turkey (ISAAC Phase III): Is a parent working in textile industry a risk factor? 2016. https://doi.org/10.5336/dermato.2014-43002

20. Tamay Z, Akcay A, Ones U, Guler N, Kilic G, Zencir M. Prevalence and risk factors for allergic rhinitis in primary school children. International journal of pediatric otorhinolaryngology. 2007;71(3):463-71. https://doi.org/10.1016/j.ijporl.2006.11.013

21. Saraçlar Y, Kuyucu S, Tuncer A, Şekerel B, Saçkesen C, Kocabaş C. Prevalence of asthmatic phenotypes and bronchial hyperresponsiveness in Turkish schoolchildren: an International Study of Asthma and Allergies in Childhood (ISAAC) phase 2 study. Annals of Allergy, Asthma \& Immunology. 2003;91(5):477-84. https://doi.org/10.1016/S1081-1206(10)61517-7

22. Rahimi Rad M, Hejazi M, Behrouzian R. Asthma and other allergic diseases in 13-14-year-old schoolchildren in Urmia: an ISAAC study. EMHJ-Eastern Mediterranean Health Journal, 13 (5), 1005-1016, 2007. 2007. https://doi.org/10.26719/2007.13.5.1005

23. Carlsen $\mathrm{KH}$, Kowalski M. Asthma, allergy, the athlete and the Olympics. Wiley Online Library; 2008. https://doi.org/10.1111/j.1398-9995.2008.01630.x

24. Kurowski M, Jurczyk J, Krysztofiak H, Kowalski ML. Exercise-induced respiratory symptoms and allergy in elite athletes: A llergy and A sthma in P olish O lympic A thletes (A2POLO) project within GA2LEN initiative. The clinical respiratory journal. 2016;10(2):231-8. https://doi.org/10.1111/crj.12210

25. Katelaris $\mathrm{CH}$, Carrozzi FM, Burke TV, Byth K. A springtime Olympics demands special consideration for allergic athletes. Journal of Allergy and Clinical Immunology. 2000;106(2):260-6. https://doi.org/10.1067/mai.2000.108603

26. Bousquet J, Khaltaev N, Cruz AA, Denburg J, Fokkens W, Togias A, et al. Allergic rhinitis and its impact on asthma (ARIA) 2008. Allergy. 2008;63:8-160.

https://doi.org/10.1111/j.1398-9995.2007.01620.x 
27. Helbling A, Müller U. Bronchial asthma in high-performance athletes. Schweizerische Zeitschrift fur Sportmedizin. 1991;39(2):77-81.

28. Lapucci G, Rasi G, Bonini S, Aloe L, Ambrosini B, Berlutti G, et al. Allergy and infectious diseases in athletes. Journal of Allergy and Clinical Immunology. 2003;111(2):S142. https://doi.org/10.1016/S0091-6749(03)80450-5

29. Bonini S, Bonini M, Bousquet J, Brusasco V, Canonica G, Carlsen $\mathrm{KH}$, et al. Rhinitis and asthma in athletes: an ARIA document in collaboration with GA2LEN. Allergy. 2006;61(6):681-92. https://doi.org/10.1111/j.1398-9995.2006.01080.x

30. Weiler JM, Layton T, Hunt M. Asthma in United States Olympic athletes who participated in the 1996 Summer Games. Journal of allergy and clinical immunology. 1998;102(5):722-6. https://doi.org/10.1016/S0091-6749(98)70010-7

31. Weiler JM, Ryan III EJ. Asthma in United States olympic athletes who participated in the 1998 olympic winter games. Journal of Allergy and Clinical Immunology. 2000;106(2):26771.

https://doi.org/10.1067/mai.2000.108605

32. Ventura M, Cannone A, Sinesi D, Buquicchio R, Carbonara M, Di Leo $E$, et al. Sensitization, asthma and allergic disease in young soccer players. Allergy. 2009;64(4):556-9. https://doi.org/10.1111/j.1398-9995.2008.01857.x

33. Macucci F, Guerrini L, Strambi M. Asthma and allergy in young athletes in Siena Province: Preliminary results. Journal of sports medicine and physical fitness. 2007;47(3):351.

34. Drobnic F, Casan P. The prevalence of asthma among the Spanish athletes participating in the Barcelona Olympic Games. Archivos de bronconeumologia. 1994;30(8):419-20. https://doi.org/10.1016/S0300-2896(15)31040-1
35. Arslan EA, Orhan F, Baki A, KarakaŞ T, Topçu IK, Can E, et al. Prevalence of exercise-induced bronchospasm in 8-18-yearold amateur or professional football players in Trabzon, Turkey.

36. McConnell R, Berhane K, Gilliland F, London SJ, Islam T, Gauderman WJ, et al. Asthma in exercising children exposed to ozone: a cohort study. The Lancet. 2002;359(9304):38691. https://doi.org/10.1016/S0140-6736(02)07597-9

37. Langdeau J-B, Boulet L-P. Prevalence and mechanisms of development of asthma and airway hyperresponsiveness in athletes. Sports Medicine. 2001;31(8):601-16. https://doi.org/10.2165/00007256-200131080-00005

38. Kang H, Yu J, Yoo Y, Kim D, Koh Y. Coincidence of atopy profile in terms of monosensitization and polysensitization in children and their parents. Allergy. 2005;60(8):1029-33. https://doi.org/10.1111/j.1398-9995.2005.00804.x

39. Woods JA, Vieira VJ, Keylock KT. Exercise, inflammation, and innate immunity. Immunology and allergy clinics of North America. 2009;29(2):381-93. https://doi.org/10.1016/j.iac.2009.02.011

40. França-Pinto A, Mendes FA, de Carvalho-Pinto RM, Agondi RC, Cukier A, Stelmach R, et al. Aerobic training decreases bronchial hyperresponsiveness and systemic inflammation in patients with moderate or severe asthma: a randomised controlled trial. Thorax. 2015;70(8):732-9. https://doi.org/10.1136/thoraxjnl-2014-206070

41. Silva R, Almeida F, Olivo C, Saraiva-Romanholo B, Martins M, Carvalho $C$. Airway remodeling is reversed by aerobic training in a murine model of chronic asthma. Scandinavian journal of medicine \& science in sports. 2015;25(3):e258-e66. https://doi.org/10.1111/sms.12311 